\title{
Cd(II) biosorption using bacterial isolates from sawdust: optimization via orthogonal array Taguchi method
}

\author{
Lekan Taofeek Popoola', Adeyinka Sikiru Yusuff', Babatunde Kazeem Adeoye² and Tajudeen Adejare Aderibigbe ${ }^{3}$ \\ 'Unit Operation and Material Science Laboratory, Chemical and Petroleum Engineering Department, Afe Babalola University, \\ Ado-Ekiti, Ekiti State, Nigeria \\ ${ }^{2}$ Department of Food Science and Technology, Federal University of Technology, Akure, Nigeria \\ ${ }^{3}$ Science Laboratory Technology Department, Yaba College of Technology, Yaba, Lagos State, Nigeria
}

Orthogonal array of Taguchi experimental design with $\mathrm{L}_{16}$ four-level factors: $\mathrm{pH}(2-8)$, temperature (303-333 $\mathrm{K}$ ), time (1-4 h), inoculum concentration (5-20 v/v) and Cd(II) initial concentration (50-200 mg/L) was applied to optimize $\mathrm{Cd}(\mathrm{II})$ biosorption from aqueous solution via bacterial isolates from sawdust. The optimum conditions were found to be $4,303 \mathrm{~K}, 4 \mathrm{~h}, 15 \mathrm{v} / \mathrm{v} \%$ and $50 \mathrm{mg} / \mathrm{L}$ for $\mathrm{pH}$, temperature, time, inoculum concentration and $\mathrm{Cd}(\mathrm{II})$ initial concentration, respectively. A confirmatory experimental run at these conditions revealed $99.53 \%$ $\mathrm{Cd}$ (II) removal. Fourier transform infrared revealed the presence of $-\mathrm{OH}$ on the bacterial surface enhancing $\mathrm{Cd}(\mathrm{II})$ biosorption. The presence of small cavities on the bacterial surface with a porous inner multilayer was shown by scanning electron microscopy analysis. Proposed biosorption mechanisms were electrostatic interaction, surface complexation and ion exchange. In conclusion, bacterial isolates from sawdust could effectively be applied as biosorbent for Cd(II) removal from aqueous solution.

\section{INTRODUCTION}

Water is among the natural resources needed for germination of crops, to achieve sustainable food production via irrigation (Hristov, 2014). Various forms of anthropogenic activities contaminate this natural resource when humans engage in industrial activities to manufacture end-products for consumption (Abdulla et al., 2019). This adversely affects the water and makes it unsuitable for agricultural purposes (fishing and irrigation). Sewage sludge and industrial effluents discharged into water bodies contain contaminants. Among these are heavy metals such as cadmium, lead, chromium, mercury and arsenic, whose presence at low concentrations stunts plant growth by altering its biochemical and physiological development, leading to chlorosis, root growth inhibition and plasma membrane damage (Bouazizi et al., 2010; Mkadmi et al., 2018; Nagendrappa et al., 2010). Declining plant growth decreases yield, which affects food supplies. Remediation of heavy metal contaminated water is thus important for food security.

In the past, physical and chemical methods (electrokinetics, solidification, soil washing, vapour extraction, encapsulation, stabilization, vitrification and so on) employed in tackling heavy metalcontaminated water have been prohibitively expensive (Popoola et al., 2018). They were not environmentally friendly and also altered the physico-chemical properties of water, thus making it unsuitable for agricultural purposes (Marques et al., 2009). Currently, researchers are focusing on applying biological techniques (bioremediation) to treat heavy metal-polluted water, because of the many advantages it offers over the previously mentioned methods (Patrón-Prado et al., 2010; Jacob et al., 2018). The most prevalent cost-effective and reliable bioremediation method is the application of microorganisms (bacteria, fungi, algae and yeast) isolated from plants to remove contaminants from polluted water (Kumar et al., 2010). Their mechanisms of heavy metal biosorption include transport across the cell membrane, complexation, ion exchange, precipitation and physical adsorption (Javanbakht et al., 2014). Studies have shown cadmium to be the highest ranked heavy metal in terms of damage caused to plant growth and human health (Ding et al., 2012; Hu et al., 2012). Saccharomyces cerevisiae (Hamza et al., 2010), dried seaweed Sargassum sinicola (Patrón-Prado et al. 2010), Spirulina sp. (Chojnacka et al., 2005), Pseudomonas plecoglossicida (Guo et al. 2012), Tetraselmis suecica (Pérez-Rama et al., 2010), NaOH-treated Mucor rouxii (Yan et al., 2003), Pseudomonas fluorescens (Sankarammal et al., 2014), Klebsiella planticola (Sharma et al., 2000), Kocuria rhizophila (Haq et al., 2015), Cystoseira barbata (Yalçın et al., 2012), dry biofilms from biotrickling filters (He et al., 2018), wheat straw (Wu et al., 2019), Musa acuminate-Solanum tuberosum peels (Rehman et al., 2019), microwave-assisted thiourea-modified Sorghum bicolor agrowaste (Salman et al., 2020), Licheniformis sp. and Laterosporus B. (Zouboulis et al., 2004) have been used for Cd(II) biosorption from polluted water.

Previously, two-level Plackett-Burman factorial design was used as an optimization tool for removal of $\mathrm{Pb}^{2+}$ using Gelidium amansii (El-Naggar et al., 2018a), and $\mathrm{Cr}^{5+}$ and $\mathrm{Cu}^{2+}$ using Aspergillus terreus (Abou-Taleb et al., 2017), while response surface methodology has been applied for removal of phenol using Pseudomonas putida (Sridevi et al., 2011) and of $\mathrm{Pb}^{2+}$ using Aspergillus niger (Amini et al., 2008) from aqueous solutions. However, application of Taguchi experimental design in different areas of wastewater treatment have gained serious attention over other experimental design methods due to

\section{CORRESPONDENCE}

Lekan Taofeek Popoola

\section{EMAIL}

Itpopoola@abuad.edu.ng

\section{DATES}

Received: 28 January 2020

Accepted: 15 September 2020

\section{KEYWORDS}

cadmium bacterial isolates biosorption aqueous solution sawdust

\section{COPYRIGHT}

() The Author(s) Published under a Creative Commons Attribution 4.0 International Licence (CC BY 4.0) 
its improved quality, and robust design (Daneshvar et al., 2007; Mousav et al., 2007; Barrado et al., 1996; Engin et al., 2008). Also, studies have shown the high resistance of Pseudomonas aeruginosa to pollutants including heavy metals, antibiotics, organic solvents and detergents (Haritash et al., 2009; Chellaiah, 2018).

This study applied $\mathrm{L}_{16}$ four-level factors $\left(4^{\wedge} 5\right)$ orthogonal array of Taguchi experimental design for investigating optimization of $\mathrm{Cd}(\mathrm{II})$ biosorption from polluted water using bacteria isolates from waste sawdust. The analysis of mean (ANOM) approach was adopted for statistical optimization of process parameters ( $\mathrm{pH}$, temperature, time, inoculum concentration and $\mathrm{Cd}(\mathrm{II})$ salt initial concentration) that influence $\mathrm{Cd}(\mathrm{II})$ biosorption from aqueous solution. Analysis of variance (ANOVA) technique was applied to check the percentage contribution of individual process parameters to the biosorption process. An experiment was conducted to correlate the predicted optimized condition by the Taguchi experimental design. Few investigations have been conducted in the past on application of bacteria isolates from sawdust as active bio-agents for the removal of $\mathrm{Cd}^{2+}$ from aqueous solution. Characterization was done using FTIR and SEM.

\section{MATERIALS AND METHODS}

\section{Waste sawdust collection}

A sawdust sample was collected from New Garage Saw Milling Industry, Ibadan, Oyo State, Nigeria. Dirt was removed from the sawdust by hand picking. It was then passed through a mesh size of $1.18 \mathrm{~mm}$ to obtain a smaller particle size. The sawdust was then washed thoroughly in distilled water and sieved. About $20 \mathrm{~kg}$ of sieved particle was later soaked in a bucket containing water at room temperature for 14 days to activate bacterial growth.

\section{Analytical chemicals}

Broth medium, nutrient agar, sodium hydroxide $(\mathrm{NaOH})$, hydrochloric acid and trihydrates of cadmium nitrate $\left(\mathrm{Cd}\left(\mathrm{NO}_{3}\right)_{2} \cdot 3 \mathrm{H}_{2} \mathrm{O}\right)$ were supplied by TopJ Scientific, Ajilosun Road, Ado-Ekiti, Nigeria. All the chemicals used were of analytical grade.

\section{Isolation and characterization of bacteria}

The dilution plate method was adopted to isolate and characterize bacterial isolates from the fermented sawdust. Ten grams of fermented sawdust was added to $90 \mathrm{~mL}$ distilled water. Twentythree grams of nutrient agar (Lifesave biotech, USA) (peptic digest of animal tissue $=5.0 \mathrm{~g} / \mathrm{L}$, beef extract $=1.50 \mathrm{~g} / \mathrm{L}$, yeast extract $=$ $1.50 \mathrm{~g} / \mathrm{L}$, sodium chloride $=5.0 \mathrm{~g} / \mathrm{L}$, agar $=15.0 \mathrm{~g} / \mathrm{L}$ and final $\mathrm{pH}$ at $25^{\circ} \mathrm{C}=7.4 \pm 0.2$ ) were dissolved in $1000 \mathrm{~mL}$ of distilled water and continuously stirred until homogeneity was ascertained. Ten different samples containing $9 \mathrm{~mL}$ of diluted sawdust and $10 \mathrm{~mL}$ of nutrient agar each were set up under aerobic conditions in a petri dish and placed in an incubator at $37^{\circ} \mathrm{C}$ for 5 days. The discrete bacterial colonies were sub-cultured and sterilized. Stock cultures were then prepared from the pure cultures and stored at $4^{\circ} \mathrm{C}$ for further laboratory work.

Bacterial isolates were characterized using the sugar fermentation test. The method described by Cheesbrough (1985) was adopted to conduct a motility test. The methods described by MacFadden (2000) were used to perform biochemical tests. The various tests executed include motility, methyl-red, catalase, glucose, sucrose, mannose, lactose, pigment, oxidase, gram reaction and citrate.

\section{Batch biosorption experiments}

\section{Preparation of $\mathrm{Cd}(\mathrm{II})$ solution}

One gram of $1 \mathrm{M} \mathrm{Cd}\left(\mathrm{NO}_{3}\right)_{2} \cdot 3 \mathrm{H}_{2} \mathrm{O}$ salt was dissolved in $1 \mathrm{~L}$ of distilled water to form simulated stock solutions in a $1000 \mathrm{~mL}$ round bottom flask. Different initial concentrations of Cd(II) solution were prepared in $200 \mathrm{~mL}$ conical flasks for batch biosorption process using a Taguchi experimental design, as shown in Table 1.

\section{Batch biosorption process}

A temperature-controlled stirrer (Stuart heat-stirrer SB162) was used to investigate the batch biosorption of Cd(II) from solution using 5-day cultured bacterial isolates. The values for $\mathrm{pH}$, temperature, time, inoculum concentration and Cd(II) salt initial concentration investigated for the batch process were based on the values specified by $\mathrm{L}_{16}$ four-level factors $\left(4^{\wedge} 5\right)$ orthogonal array of Taguchi experimental design (Ghani et al., 2013) as presented in Table 2 (16 experimental runs). The $\mathrm{pH}$ of the solution was varied using $1 \mathrm{M} \mathrm{HCl}$ and $1 \mathrm{M} \mathrm{KOH}$ aqueous solutions. Constant values of $100 \mathrm{~mL}$ of $\mathrm{Cd}(\mathrm{II})$ salt in $250-\mathrm{mL}$ flasks and $130 \mathrm{r} / \mathrm{min}$ were used throughout the experiment. Whatman PTFE filter paper was used to separate the filtrate from the residue. Cd(II) concentration was measured using an atomic absorption spectrometer (AAS Buck Scientific 210 VGP, USA). The concentrations of Cd(II) in the solution after a specified time were measured at a dilution factor of 50 and average values were recorded. The potential of bacterial isolates from sawdust to remove Cd(II) from solution was determined by measuring the percentage of $\mathrm{Cd}(\mathrm{II})$ adsorbed using Eq. 1.

$$
\% \mathrm{Cd}(\mathrm{II}) \text { Sorption }=\frac{\left(C_{o}-C_{t}\right)}{C_{o}} \times 100 \%
$$

where $C_{o}$ is the initial concentration of $\mathrm{Cd}(\mathrm{II})(\mathrm{mg} / \mathrm{L})$ and $C_{t}$ is the final concentration of $\mathrm{Cd}(\mathrm{II})(\mathrm{mg} / \mathrm{L})$ after each experimental run.

\section{Optimization studies using analysis of mean technique}

In order to execute optimization studies for Cd(II) biosorption from aqueous solution using bacterial isolates from sawdust, 5 operation factors were examined such that each of them was set at 4 different levels, as presented in Table 1 . The experimental conditions for optimum biosorption of Cd(II) were determined using $\mathrm{L}_{16}$ orthogonal array of Taguchi experimental design as presented in Table 2. Signal-to-noise $(\mathrm{S} / \mathrm{N})$ ratio was calculated using Eq. 2 (Pundir et al., 2018) for statistical analysis to maximize the process conditions for optimum biosorption.

$$
\frac{S}{N}=-10 \log \left(\frac{1}{n} \sum_{i=1}^{n} \frac{1}{R_{i}^{2}}\right)
$$

where $n=$ number of replications for each experimental run and $R_{i}=$ percentage $\mathrm{Cd}(\mathrm{II})$ removed from solution in replication experiment $i$ executed under the same experimental conditions for each test run.

The average $\mathrm{S} / \mathrm{N}$ ratio value of each process parameter at a particular level was calculated using Eq. 3:

$$
(M)_{\text {Level }=i}^{\text {Factor }=F}=\frac{1}{n_{F i}} \sum_{j=1}^{n_{F i}}\left[\left(\frac{S}{N}\right)_{\text {Level }=i}^{\text {Factor }=F}\right]_{j}
$$

where $(M)_{\text {Level }=i}^{\text {Factor } F}=$ mean value of $\mathrm{S} / \mathrm{N}$ ratio with factor $F$ at level $i$, $\left[\left(\frac{S}{N}\right)_{\text {Level }=i}^{\text {Factor }=F}\right]_{j}=\mathrm{S} / \mathrm{N}$ ratio value with factor $F$ at level $i$ in its $j^{\text {th }}$ appearance $(j=1,2,3$ and 4$)$ and $n_{F i}=$ number of appearances of factor $F$ in level $i$. 
Table 1. Biosorption process parameters and levels using $\mathrm{L}_{16}$ Taguchi experimental design orthogonal array

\begin{tabular}{|c|c|c|c|c|c|c|}
\hline Factor code & Parameter & Unit & Level 1 (L1) & Level 2 (L2) & Level 3 (L3) & Level 4 (L4) \\
\hline$A$ & $\mathrm{pH}$ & - & 2 & 4 & 6 & 8 \\
\hline B & Temperature & $\mathrm{K}$ & 303 & 313 & 323 & 333 \\
\hline $\mathrm{C}$ & Time & $\mathrm{hr}$ & 1 & 2 & 3 & 4 \\
\hline $\mathrm{D}$ & Inoculum concentration & $\mathrm{v} / \mathrm{v}(\%)$ & 5 & 10 & 15 & 20 \\
\hline$E$ & $\mathrm{Cd}(\mathrm{II})$ initial concentration & $\mathrm{mg} / \mathrm{L}$ & 50 & 100 & 150 & 200 \\
\hline
\end{tabular}

Table 2. Experimental runs

\begin{tabular}{|c|c|c|c|c|c|}
\hline \multirow[t]{2}{*}{ Run } & $\mathrm{pH}$ & Temperature (K) & Time (h) & Inoculum conc. (v/v \%) & $\mathrm{Cd}(\mathrm{II})$ initial conc. (mg/L) \\
\hline & (A) & (B) & (C) & (D) & (E) \\
\hline 1 & 6 & 333 & 2 & 5 & 150 \\
\hline 2 & 2 & 313 & 2 & 10 & 100 \\
\hline 3 & 4 & 333 & 3 & 10 & 50 \\
\hline 4 & 6 & 313 & 4 & 15 & 50 \\
\hline 5 & 8 & 333 & 1 & 15 & 100 \\
\hline 6 & 4 & 313 & 1 & 20 & 150 \\
\hline 7 & 4 & 303 & 2 & 15 & 200 \\
\hline 8 & 8 & 313 & 3 & 5 & 200 \\
\hline 9 & 2 & 303 & 1 & 5 & 50 \\
\hline 10 & 8 & 303 & 4 & 10 & 150 \\
\hline 11 & 2 & 333 & 4 & 20 & 200 \\
\hline 12 & 2 & 323 & 3 & 15 & 150 \\
\hline 13 & 8 & 323 & 2 & 20 & 50 \\
\hline 14 & 6 & 323 & 1 & 10 & 200 \\
\hline 15 & 6 & 303 & 3 & 20 & 100 \\
\hline 16 & 4 & 323 & 4 & 5 & 100 \\
\hline
\end{tabular}

\section{Determination of factor percentage contribution using analysis of variance}

Analysis of variance (ANOVA) was employed to determine the percentage contribution of each process factor $\left(P_{F}\right)$ to $\mathrm{Cd}(\mathrm{II})$ biosorption using Eq. 4:

$$
\rho_{F}=\frac{S S_{F}-\left(D O F_{F} \times V_{E r}\right)}{S S_{T}} \times 100
$$

where $\mathrm{SS}_{\mathrm{F}}, \mathrm{DOF}_{\mathrm{F}}, V_{\mathrm{Er}}$ and $\mathrm{SS}_{\mathrm{T}}$ are factorial sum of squares, degrees of freedom of each factor, variance of error and total sum of squares expressed as Equations 5, 6, 7 and 8, respectively.

$$
\begin{gathered}
S S_{F}=\frac{m n}{L} \sum_{k=1}^{L}\left((\bar{R})_{k}^{F}-\bar{R}_{T}\right) \\
D O F_{F}=L-1 \\
V_{E r}=\frac{S S_{T}-\sum_{F=A}^{D} S S_{F}}{m(n-1)} \\
S S_{T}=\sum_{j=1}^{m}\left(\sum_{i=1}^{n} R_{i}^{2}\right)_{j}-m n\left(\bar{R}_{T}\right)^{2}
\end{gathered}
$$

where

$m=$ number of experiments executed

$n=$ number of replications of each experiment

$L=$ number of levels of each factor

$(\bar{R})_{k}^{F}=$ cumulative average of $\mathrm{Cd}(\mathrm{II})$ percentage removal with a certain factor $F$ at $k^{\text {th }}$ level (expressed as Eq. 9)
$\bar{R}_{T}=$ cumulative average of $\mathrm{Cd}(\mathrm{II})$ removed from solution (expressed as Eq. 10).

where

$$
(\bar{R})_{k}^{F}=\frac{1}{n_{F k}} \sum_{j=1}^{n_{F k}}\left[(\bar{A})_{\text {level }=k}^{\text {Factor }=F}\right]_{j}
$$

$n_{F k}=$ number of factor $F$ appearances at level $k$

$\left[(\bar{A})_{\text {level }=k}^{\text {Factor }=F}\right]_{j}=$ average $\mathrm{Cd}(\mathrm{II})$ percentage removal $(\bar{A})$ with a

factor $F$ at level $k$ in its $j^{\text {th }}$ appearance sequence $\left(j=1,2,3 \ldots . n_{F k}\right)$.

$$
\bar{R}_{T}=\frac{\sum_{j=1}^{m}\left(\sum_{i=1}^{n} R_{i}\right)_{j}}{m n}
$$

where $R_{i}=$ percentage $\mathrm{Cd}(\mathrm{II})$ removed from solution in replication experiment $i$ executed under the same experimental conditions for each test run.

\section{Characterization of the bacterial cell surface}

The active functional groups present on the surface of the bacterial isolates were investigated using Fourier-transform infrared spectroscopy (Nicolet iS10 FT-IR Spectrometer, USA) within a wavelength of 400-4 $000 \mathrm{~cm}^{-1}$. Beams of infrared were directed at the sample. The quantity and frequencies at which samples absorbed IR light were measured. The sample molecular identities were determined using the reference database.

The morphology of the bacteria was studied using a scanning electron microscope (SEM-JEOL-JSM 7600F) operated under high-vacuum evaporation at $5000 \times, 15 \mathrm{kV}$. The sample was coated using a low-vacuum sputter platinum coating and then placed in a relative high-pressure chamber. The electron optical 
column was differentially pumped to ensure that the vacuum was kept adequately low. Secondary electron signal amplification was provided by the high-pressure region around the sample which neutralizes the charge. Due to the field emission gun's (FEG) ability to produce high primary electron brightness, low-voltage SEM was used in the FEG-SEM.

\section{RESULTS AND DISCUSSION}

\section{Calculation of average percentage Cd(II) removal and signal-to-noise ratio at factor levels}

Equation 1 was used to determine the percentage of $\mathrm{Cd}(\mathrm{II})$ removed from aqueous solution $\left(A_{i}\right)$ for each of the experimental tests, which were replicated for $i=1,2,3$ and 4 for specified values of $\mathrm{pH}(2,4,6$ and 8$)$, temperature $(303,313,323$ and $333 \mathrm{~K})$, time (1, 2, 3 and $4 \mathrm{hrs})$, inoculum concentration $(5,10,15$ and $20 \mathrm{v} / \mathrm{v} \%)$ and Cd(II) initial concentration (50, 100, 150 and 200 $\mathrm{mg} / \mathrm{L}$ ) as stated in Table 1 . The results obtained for $A_{i}$, average of responses for the experimental runs $\left(\bar{A}_{i}\right)$ and signal-to-noise ratio (calculated by using Eq. 2) (S/N) are presented in Table 3. Equation 3 was used to estimate the average $\mathrm{S} / \mathrm{N}$ ratio values (presented in Table 4) for a certain factor at a certain level $\left(M_{\text {Level }}^{\text {Factor }}\right)$, while Eq. 9 was used to calculate the average $\mathrm{Cd}(\mathrm{II})$ removed from aqueous solution (presented in Table 5) for a certain factor at a certain level $\left(\bar{R}_{\text {Level }}^{\text {Factor }}\right)$. The average percentage Cd(II) removed from aqueous solution and respective $\mathrm{S} / \mathrm{N}$ ratio at different levels of $\mathrm{pH}$, temperature, time, inoculum concentration and $\mathrm{Cd}(\mathrm{II})$ initial concentration are presented as Figs 1-5, respectively.

Table 3. Percentages of $\mathrm{Cd}(\mathrm{II})$ removed from aqueous solution and $\mathrm{S} / \mathrm{N}$ ratios

\begin{tabular}{|c|c|c|c|c|c|c|}
\hline \multirow[t]{2}{*}{ Test } & \multicolumn{5}{|c|}{$\mathrm{Cd}(\mathrm{II})$ removed $(\%)$} & \multirow[t]{2}{*}{$\mathrm{S} / \mathrm{N}$ ratio } \\
\hline & Response $1\left(A_{1}\right)$ & Response $2\left(A_{2}\right)$ & Response $3\left(A_{3}\right)$ & Response $4\left(A_{4}\right)$ & Average response $(\bar{A})$ & \\
\hline 1 & 87.17 & 91.36 & 95.68 & 88.5 & 90.68 & 39.13 \\
\hline 2 & 88.5 & 80.5 & 88.25 & 83.9 & 85.29 & 38.60 \\
\hline 3 & 94.42 & 81.51 & 85.36 & 86.48 & 86.94 & 38.75 \\
\hline 4 & 97.07 & 89.1 & 93.28 & 86.81 & 91.57 & 39.21 \\
\hline 5 & 95.5 & 88.27 & 98.77 & 92.61 & 93.79 & 39.42 \\
\hline 6 & 82.91 & 84.42 & 87.02 & 73.33 & 81.92 & 38.21 \\
\hline 7 & 77.32 & 81.06 & 99.34 & 86.92 & 86.16 & 38.59 \\
\hline 8 & 92.7 & 93.23 & 92.65 & 98.84 & 94.36 & 39.49 \\
\hline 9 & 81.81 & 87.29 & 83.87 & 81.03 & 83.50 & 38.42 \\
\hline 10 & 83.76 & 95.46 & 94.25 & 94.52 & 92.00 & 39.24 \\
\hline 11 & 91.29 & 77.71 & 85.36 & 94.28 & 87.16 & 38.73 \\
\hline 12 & 89.63 & 96.93 & 76.3 & 93.5 & 89.09 & 38.89 \\
\hline 13 & 98.93 & 75.32 & 78.62 & 96.77 & 87.41 & 38.64 \\
\hline 14 & 88.01 & 97.64 & 94.08 & 91.6 & 92.83 & 39.34 \\
\hline 15 & 91.72 & 89.07 & 89.15 & 74.8 & 86.19 & 38.62 \\
\hline 16 & 80.51 & 93.37 & 91.2 & 90.01 & 88.77 & 38.92 \\
\hline
\end{tabular}

Table 4. S/N ratio of responses at factor levels

\begin{tabular}{|c|c|c|c|c|c|}
\hline \multirow[t]{2}{*}{ Factor level } & \multicolumn{4}{|c|}{$\left[\left(\frac{S}{N}\right)_{\text {Level }}^{\text {Factor }}\right]_{j}$} & \multirow{2}{*}{$(M)_{\text {Level }}^{\text {Factor }}$} \\
\hline & $j=1$ & $j=2$ & $j=3$ & $j=4$ & \\
\hline $\mathrm{A} / 1$ & 39.13 & 38.6 & 38.75 & 39.21 & 38.92 \\
\hline $\mathrm{A} / 2$ & 39.42 & 38.21 & 38.59 & 39.49 & 38.93 \\
\hline $\mathrm{A} / 3$ & 38.42 & 39.24 & 38.73 & 38.89 & 38.82 \\
\hline $\mathrm{A} / 4$ & 38.64 & 39.34 & 38.62 & 38.92 & 38.88 \\
\hline $\mathrm{B} / 1$ & 39.13 & 39.42 & 39.49 & 38.64 & 39.17 \\
\hline $\mathrm{B} / 2$ & 38.60 & 38.21 & 39.24 & 39.34 & 38.85 \\
\hline $\mathrm{B} / 3$ & 38.75 & 38.59 & 38.73 & 38.62 & 38.67 \\
\hline$B / 4$ & 38.21 & 39.49 & 38.60 & 38.92 & 38.80 \\
\hline $\mathrm{C} / 1$ & 39.13 & 38.64 & 39.24 & 38.21 & 38.81 \\
\hline $\mathrm{C} / 2$ & 38.60 & 39.42 & 38.73 & 38.62 & 38.84 \\
\hline $\mathrm{C} / 3$ & 38.75 & 38.42 & 38.89 & 39.49 & 38.89 \\
\hline $\mathrm{C} / 4$ & 39.21 & 38.59 & 39.42 & 39.13 & 39.09 \\
\hline $\mathrm{D} / 1$ & 39.13 & 38.21 & 38.73 & 38.92 & 38.75 \\
\hline $\mathrm{D} / 2$ & 38.60 & 38.59 & 38.42 & 38.64 & 38.56 \\
\hline $\mathrm{D} / 3$ & 38.75 & 39.49 & 39.24 & 39.34 & 39.20 \\
\hline $\mathrm{D} / 4$ & 39.21 & 39.42 & 38.89 & 38.62 & 39.03 \\
\hline$E / 1$ & 39.13 & 39.49 & 38.62 & 38.62 & 38.97 \\
\hline$E / 2$ & 38.60 & 38.73 & 38.64 & 38.92 & 38.72 \\
\hline$E / 3$ & 38.75 & 38.89 & 39.34 & 38.64 & 38.90 \\
\hline $\mathrm{E} / 4$ & 39.21 & 38.42 & 38.92 & 38.21 & 38.69 \\
\hline
\end{tabular}

Table 5. Percentage removal of $\mathrm{Cd}(\mathrm{II})$ at factor levels

\begin{tabular}{|c|c|c|c|c|c|}
\hline \multirow[t]{2}{*}{ Factor level } & \multicolumn{4}{|c|}{$\left[(\bar{A})_{\text {Level }}^{\text {Factor }}\right]_{j}$} & \multirow[t]{2}{*}{$(\bar{R})_{\text {Level }}^{\text {Factor }}$} \\
\hline & $j=1$ & $j=2$ & $j=3$ & $j=4$ & \\
\hline $\mathrm{A} / 1$ & 89.59 & 93.20 & 82.27 & 92.09 & 89.29 \\
\hline $\mathrm{A} / 2$ & 78.28 & 88.25 & 89.84 & 93.20 & 87.39 \\
\hline$A / 3$ & 92.59 & 79.59 & 80.69 & 94.62 & 86.87 \\
\hline $\mathrm{A} / 4$ & 90.79 & 97.98 & 90.79 & 93.37 & 93.23 \\
\hline$B / 1$ & 89.59 & 92.59 & 92.59 & 90.79 & 91.39 \\
\hline$B / 2$ & 93.20 & 88.25 & 92.95 & 79.59 & 88.50 \\
\hline$B / 3$ & 82.27 & 89.84 & 93.37 & 88.25 & 88.43 \\
\hline$B / 4$ & 92.09 & 79.59 & 89.59 & 82.27 & 85.88 \\
\hline $\mathrm{C} / 1$ & 89.59 & 80.69 & 88.25 & 89.84 & 87.09 \\
\hline $\mathrm{C} / 2$ & 93.20 & 78.28 & 89.84 & 97.98 & 89.83 \\
\hline $\mathrm{C} / 3$ & 94.62 & 88.25 & 97.98 & 89.25 & 92.53 \\
\hline $\mathrm{C} / 4$ & 93.20 & 93.37 & 89.59 & 94.62 & 92.70 \\
\hline $\mathrm{D} / 1$ & 89.59 & 88.25 & 80.69 & 93.37 & 87.97 \\
\hline $\mathrm{D} / 2$ & 93.20 & 89.84 & 94.62 & 90.79 & 92.11 \\
\hline$D / 3$ & 82.27 & 97.98 & 92.59 & 97.98 & 92.70 \\
\hline $\mathrm{D} / 4$ & 92.09 & 89.59 & 97.98 & 94.62 & 93.57 \\
\hline$E / 1$ & 94.62 & 93.37 & 94.62 & 90.79 & 93.35 \\
\hline$E / 2$ & 82.27 & 97.98 & 92.59 & 93.37 & 91.55 \\
\hline$E / 3$ & 82.27 & 78.28 & 92.95 & 90.79 & 86.07 \\
\hline$E / 4$ & 92.09 & 88.25 & 80.69 & 79.59 & 85.15 \\
\hline
\end{tabular}




\section{Process parameter analysis}

\section{Solution $\mathrm{pH}$}

The effect of solution $\mathrm{pH}$ on percentage of $\mathrm{Cd}(\mathrm{II})$ removed from aqueous solution and signal-to-noise ratio was investigated (Fig. 1). It was observed that the percentage of Cd(II) removed from solution decreased from 89.29 to $86.87 \%$ when the solution $\mathrm{pH}$ was increased from 2 to 6 . This could be attributed to inactivity and death of some cells (reduction in population) of the bacterial isolates due to the presence of strong acid (Yan et al. 2003). Also, functional groups on the outer surface of the bacteria become positively charged at lower $\mathrm{pH}$, thereby creating repulsion between their surface and Cd(II) in solution which reduces heavy metal removal from solution (Yan et al. 2003). Previous studies have reported reduced heavy metal removal from solution using microorganisms at a lower $\mathrm{pH}$ of 3 (Kassab et al., 2006; Engin et al., 2008). However, the percentage of $\mathrm{Cd}(\mathrm{II})$ removed from aqueous solution drastically increased in the basic medium $(\mathrm{pH}=8)$ (Marques et al., 2009), which gives a favourable environmental condition that enhances the bacterial growth and thus increased their efficiency to remove more Cd(II) from solution. Also, the existence of negative charges at the surface of the bacteria at the higher $\mathrm{pH}$ value of 8 enhanced the strong electrostatic force between the negatively charged surface and $\mathrm{Cd}(\mathrm{II})$ in solution. Nevertheless, the presence of potassium in the $\mathrm{KOH}$ used to adjust the solution $\mathrm{pH}$ might have provided a nutrient source for the bacterial isolates' growth (Atlas et al., 1973). A similar study revealed formation of hydroxyl complexes, starting from $\mathrm{pH} 7$, resulting from electrostatic interaction (Kassab et al., 2006) Previous studies have also revealed similar results for removal of nickel (Aka et al., 2016) and lead (Kassab et al., 2006) from solution using bacterial isolates from sawdust.

\section{Reaction temperature}

The effect of temperature on the average percentage Cd(II) removed from solution (in the presence of bacterial isolates) and signal-to-noise ratio is shown in Fig. 2. The result revealed

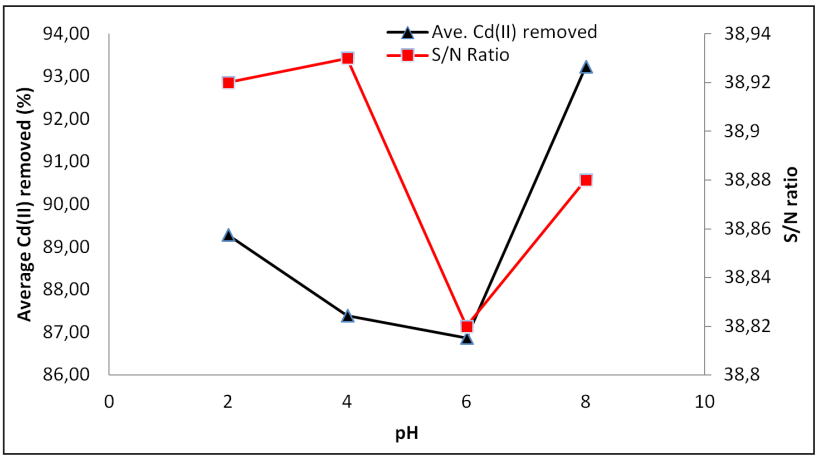

Figure 1. Solution $\mathrm{pH}$ against average $\mathrm{Cd}(\mathrm{II})$ removed and $\mathrm{S} / \mathrm{N}$ ratio

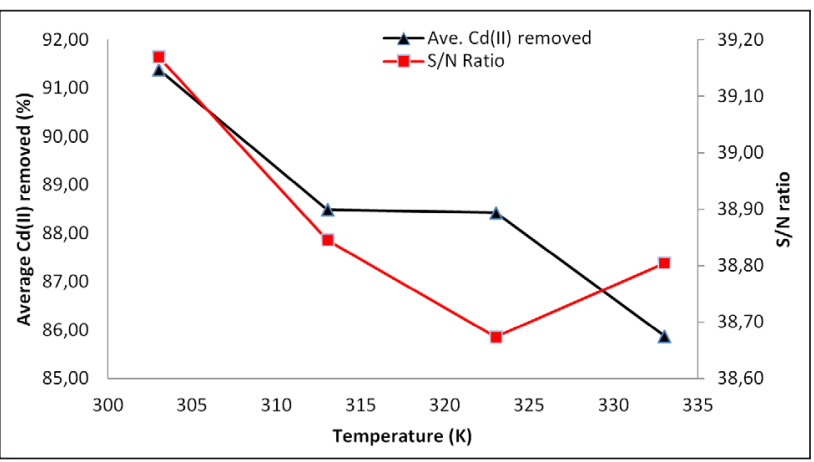

Figure 2. Solution temperature against average $\mathrm{Cd}(\mathrm{II})$ removed and $\mathrm{S} / \mathrm{N}$ ratio a decrease in the average percentage of Cd(II) removed from solution from 91.39 to $85.88 \%$ when the reaction temperature was increased from 303 to $333 \mathrm{~K}$. This resulted from damage to proteins present in bacterial colonies, which in turn reduced their growth rate and metabolic activities at this higher temperature (Huang et al. 2016). Research has revealed that bacterial efficacy in removing heavy metals from solution varies from one to another under different temperature conditions (Kumar et al., 2010; Javanbakht et al., 2014). Some studies have produced similar results to the current study (Yan et al., 2003; Sankarammal et al., 2014).

\section{Reaction time}

Figure 3 presents the variation of average Cd(II) uptake from solution by bacterial isolates and signal-to-noise ratio at different levels of reaction time. As the reaction time increases, more of the $\mathrm{Cd}(\mathrm{II})$ was removed from solution by the bacteria as a result of an increase in their growth resulting from the formation of more colonies. However, partial equilibrium was attained after $3 \mathrm{~h}$, substantiating the efficiency of the bacterial colonies in removing $\mathrm{Cd}(\mathrm{II})$ from aqueous solution as the percentage of heavy metal removed was almost constant. A high importance of reaction time in biosorption processes for heavy metals has been reported in several studies (Popoola, 2019a; Rao et al., 2006). Various equilibrium times attained for $\mathrm{Cd}(\mathrm{II})$ removal from solution have been reported, as $45 \mathrm{~min}$ (Haq et al., 2015), $90 \mathrm{~min}$ (Popoola, 2019b) and $120 \mathrm{~min}$ (Singh et al., 2000).

\section{Inoculum concentration}

A plot of inoculum concentration against average $\mathrm{Cd}(\mathrm{II})$ removed and $\mathrm{S} / \mathrm{N}$ ratio is shown in Fig. 4. The average percentage $\mathrm{Cd}(\mathrm{II})$ removed from aqueous solution increased with an increase in the concentration of inoculums. A lower percentage removal of Cd(II) (87.97\%) recorded at lower inoculum concentration (5 v/v \%) resulted from lower populations of bacteria available to remove the heavy metal from solution. However, greater bacterial growth was observed at increased inoculum concentration $(20 \mathrm{v} / \mathrm{v} \%)$, which facilitated the biosorption of $\mathrm{Cd}(\mathrm{II})$ from solution.

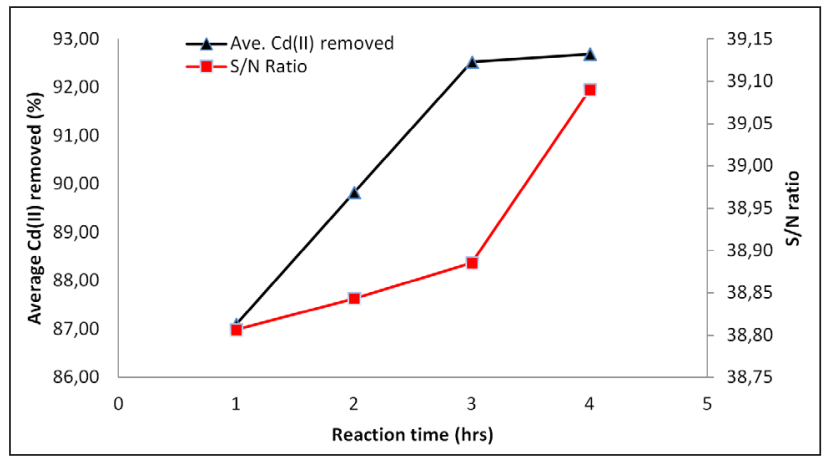

Figure 3. Reaction time against average $\mathrm{Cd}(\mathrm{II})$ removed and $\mathrm{S} / \mathrm{N}$ ratio

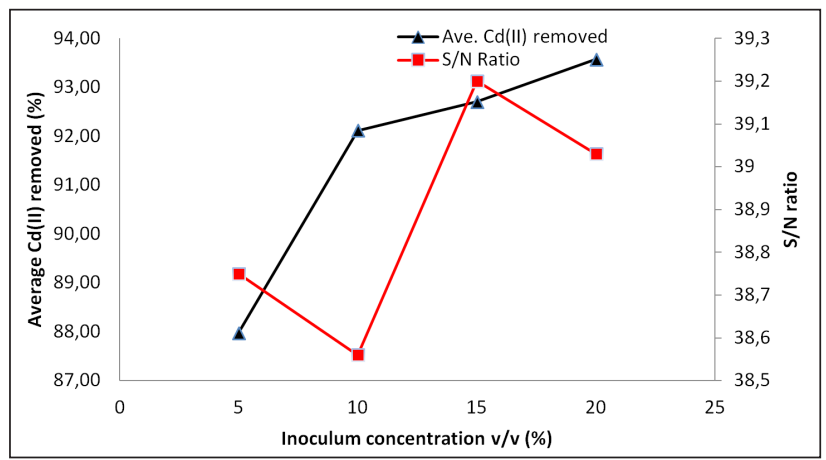

Figure 4. Inoculum concentration against average $\mathrm{Cd}(\mathrm{II})$ removed and $\mathrm{S} / \mathrm{N}$ ratio 


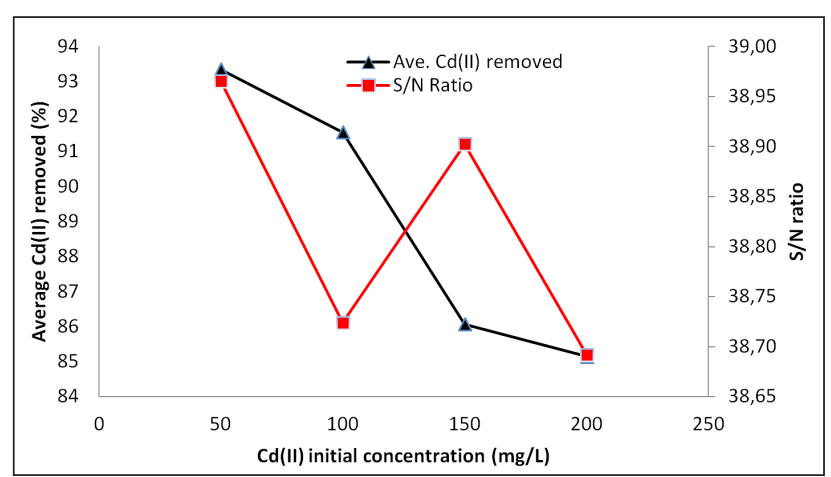

Figure 5. $\mathrm{Cd}(\mathrm{II})$ initial concentration against average $\mathrm{Cd}(\mathrm{II})$ removed and $\mathrm{S} / \mathrm{N}$ ratio

At this point, more negatively charged bacteria having a greater total surface area were available at a constant $\mathrm{pH}$ of 8 (Dursun et al., 2003). The higher the concentration of biosorbent, the higher the efficiency of heavy metal removal from solution (Yalçın et al., 2012; Zouboulis et al., 2004).

\section{Cd(II) initial concentration}

Figure 5 presents a plot showing the effect of increased initial concentration of $\mathrm{Cd}$ (II) on the efficiency of bacterial isolates from sawdust in removing it from solution, and on the signal-to-noise ratio. It was observed that the percentage of $\mathrm{Cd}$ (II) removed from solution decreased slowly from 93.35 to $85.15 \%$ when $\mathrm{Cd}(\mathrm{II})$ initial concentration was increased from $50 \mathrm{mg} / \mathrm{L}$ to $200 \mathrm{mg} / \mathrm{L}$. This observation could be attributed to: (i) reduction of binding sites (active agent of Cd(II) removal) on bacteria surface due to a reduction in their growth; (ii) inhibitory effect of cadmium salt on the bacterial growth which destroys the protein part of the bacteria; and (iii) presence of excess $\mathrm{Cd}$ (II) ions in solution which eventually reduced the accessibility of available binding sites to the heavy metal. Similar previous studies have also reported this observation for the removal of other heavy metals using microorganisms (Patrón-Prado et al., 2010; Kumar et al., 2010; Javanbakht et al., 2014; Hamza et al., 2010).

\section{Predictive mathematical model development}

In this study, the effect of 5 factors placed at 4 levels - $\mathrm{pH}(2,4,6$ and 8$)$, temperature $(303,313,323$ and $333 \mathrm{~K})$, time $(1,2,3$ and $4 \mathrm{~h}$ ), inoculum concentration (5, 10, 15 and $20 \mathrm{v} / \mathrm{v} \%), \mathrm{Cd}(\mathrm{II})$ initial concentration $(50,100,150$ and $200 \mathrm{mg} / \mathrm{L})$ - was investigated using orthogonal arrays generated by design-expert (7.0.0). The experimental values obtained for the average percentage of $\mathrm{Cd}(\mathrm{II})$ removed from water using bacterial isolates from sawdust at different factor levels are presented in Figs 1-5. A general predictive model (developed using the Taguchi approach) which could be used to establish an empirical relationship between the average percentage of $\mathrm{Cd}^{2+}$ removed from water and independent process variables is stated as Eq. 11:

$$
\begin{aligned}
& \text { Average } C d^{2+} \text { removed }(\%)=+81.67-2.39 A[1]-3.63 A[2]+ \\
& 2.17 A[3]-2.17 B[1]-3.15 B[2]+0.52 B[3]-2.79 C[1]- \\
& 0.74 C[2]+6.99 C[3]+3.01 D[1]-2.70 D[2]+1.95 D[3]- \\
& 0.67 E[1]+4.79 E[2]-1.37 E[3]
\end{aligned}
$$

where $A, B, C, D$ and $E$ represent $\mathrm{pH}$, temperature, time, inoculum concentration and $\mathrm{Cd}(\mathrm{II})$ initial concentration, respectively. The values indicated within the square brackets represent levels of the corresponding model terms.

\section{Application of analysis of variance to evaluate factor percentage contribution}

The value of $\bar{R}_{T}$ was calculated using Eq. 10 to analyse the percentage contribution of $\mathrm{pH}$, temperature, reaction time, inoculum volume and Cd(II) initial concentration towards Cd(II) removal from aqueous solution by bacterial isolates. The calculated value of $\bar{R}_{T}$ was 88.60 . The factorial sum of squares, $\mathrm{SS}_{\mathrm{F}}$, for each factor (Table 6), was calculated via substitution of $\bar{R}_{T}$ and $\bar{R}_{k}^{F}$ into Eq. 5. The value of total sum of squares $\left(\mathrm{SS}_{\mathrm{T}}\right)$ calculated via Eq. 8 was 535.85 . The value of variance of error $\left(V_{E r}\right)$ calculated by substituting $\mathrm{SS}_{\mathrm{F}}$ and $\mathrm{SS}_{\mathrm{T}}$ into Eq. 7 was 4.34. Thus, substitution of $\mathrm{DOF}_{\mathrm{F}}=3, \mathrm{SS}_{\mathrm{T}}$ and $\mathrm{SS}_{\mathrm{F}}$ into Eq. 4 gives the percentage contribution of each factor $\left(\rho_{\mathrm{F}}\right)$ (Table 6) to $\mathrm{Cd}(\mathrm{II})$ removal from aqueous solution using bacterial isolates from sawdust.

The result obtained (Table 6) revealed the influence of each of the examined parameters (measured as a percentage) on $\mathrm{Cd}(\mathrm{II})$ biosorption from aqueous solution by bacterial isolates from sawdust. The order of influence was observed to be Cd(II) initial concentration $(33.87 \%)>$ time $(26.14 \%)>$ inoculum concentration $(20.05 \%)>$ temperature $(8.64 \%)>\mathrm{pH}(6.07 \%)$. Studies have shown that the higher the initial concentration of heavy metal, the lower its removal from solution by adsorbents (Popoola, 2019b; Amini et al., 2008). Thus, initial concentration of a heavy metal greatly influences the rate of its biosorption from solution. This is because a high concentration of $\mathrm{Cd}(\mathrm{II})$ in solution hinders the growth of bacteria which adversely affects its efficiency in removing Cd(II) from solution. Hence, this affirms that the parameter with the greatest influence is $\mathrm{Cd}(\mathrm{II})$ initial concentration.

A recent study did not consider reaction time as part of the factors that affect removal of nickel and copper using Aspergillus sp. (Pundir et al., 2018). In the current study, it was revealed that the longer the inoculum stays in solution, the more the Cd(II) was removed (Fig. 3). Thus, the influence of reaction time cannot be underestimated; it ranks second, with a percentage contribution of $26.14 \%$.

Also, the influence of inoculum concentration cannot be overlooked as more bacterial colonies are formed with increases in the initial concentration of inoculum. The rate of $\mathrm{Cd}(\mathrm{II})$ removal from solution was greatly affected by increasing bacterial isolate populations, leading to an increase in percentage removal for the heavy metal. Thus, inoculum concentration was revealed to be the third most influential parameter, with a percentage contribution of $20.05 \%$. Similar studies have revealed similar results (Kumar et al., 2010; Hamza et al., 2010).

Nevertheless, temperature is another factor that also influences the removal of heavy metal from solution using microorganisms (Ding et al., 2012). In this study, the percentage contribution of temperature to the biosorption process was revealed to be $8.64 \%$ and it occupied $4^{\text {th }}$ position. Microbial growth is hindered when subjected to higher temperatures as the protein nature of bacteria is altered under these conditions (Sankarammal et al., 2014). Thus, the higher the temperature, the lower the bacterial efficiency and the more adversely removal of $\mathrm{Cd}(\mathrm{II})$ from solution is affected.

Influence of solution $\mathrm{pH}$ on heavy metal removal from solution using microorganisms has been documented previously (Dursun et al., 2003; Aksu et al., 2000). The present study revealed $\mathrm{pH}$ as having the lowest contribution ( $5^{\text {th }}$ position), with a percentage influence of $6.07 \%$ on $\mathrm{Cd}(\mathrm{II})$ biosorption from aqueous solution.

Table 6. Factorial sum of squares and percentage contribution of each factor

\begin{tabular}{lcc}
\hline Factor & $\mathrm{SS}_{\mathrm{F}}$ & $\rho_{\mathrm{F}}$ \\
\hline A & 33.59 & 6.07 \\
B & 47.34 & 8.64 \\
C & 141.14 & 26.14 \\
D & 108.48 & 20.05 \\
E & 182.54 & 33.87 \\
\hline
\end{tabular}


Solution $\mathrm{pH}$ determines the nature of the charge (either positive or negative) on the surface of the bacteria, and thereby determines the nature of the force (repulsion or attraction) between the bacteria and the heavy metal ions.

\section{ANOM technique for process parameter optimization}

The significance of $\mathrm{S} / \mathrm{N}$ ratio plotted in Figs $1-5$ was as a tool for process parameter optimization. The optimum condition is measured at factor-level combination where the $\mathrm{S} / \mathrm{N}$ ratio has the maximum value. Maximum values of $\mathrm{S} / \mathrm{N}$ ratio were recorded to be 38.93 (Fig. 1), 39.17 (Fig. 2), 39.09 (Fig. 3), 39.20 (Fig. 4) and 38.97 (Fig. 5), where $\mathrm{pH}$, temperature, time, inoculum concentration and $\mathrm{Cd}(\mathrm{II})$ initial concentration were $4,303 \mathrm{~K}$, $4 \mathrm{~h}, 15 \mathrm{v} / \mathrm{v} \%$ and $50 \mathrm{mg} / \mathrm{L}$, respectively. Thus, the factor-level combination that gives optimum Cd(II) removal from solution using bacterial isolates from sawdust was A2, B1, C4, D3 and E1. A similar study where only 4 factors were considered presented similar results for optimum biosorption of copper and nickel from solution using Aspergillus sp. fungi (Pundir et al., 2018).

In order to confirm the efficacy of bacteria isolates from sawdust in removing $\mathrm{Cd}(\mathrm{II})$ from aqueous solution, a laboratory test was conducted at the predicted optimum condition $(\mathrm{pH}=4$, temperature $=303 \mathrm{~K}$, time $=4 \mathrm{~h}$, inoculum concentration $=$ $15 \mathrm{v} / \mathrm{v} \%$ and Cd(II) initial concentration $=50 \mathrm{mg} / \mathrm{L}$ ) to calculate the percentage of heavy metal removal. At these parameter levels, the percentage of Cd(II) removed was $99.53 \%$. This reveals the efficiency of the bacteria used to remove Cd from solution at optimum operating conditions. Table 7 compares the conditions at which optimum removal of $\mathrm{Cd}(\mathrm{II})$ was achieved in this study with results from the literature.

\section{Effect of parameter interaction on Cd(II) removal}

Figure 6 represents the 3D surface plot showing effects of interaction of $\mathrm{pH}$ and temperature (Fig. 6a), $\mathrm{pH}$ and time (Fig. 6b), $\mathrm{pH}$ and inoculum concentration (Fig. 6c), $\mathrm{pH}$ and $\mathrm{Cd}(\mathrm{II})$ initial concentration (Fig. 6d), temperature and time (Fig. 6e), temperature and inoculum concentration (Fig. 6f), temperature and $\mathrm{Cd}(\mathrm{II})$ initial concentration (Fig. 6g), time and inoculum concentration (Fig. 6h), time and Cd(II) initial concentration (Fig. 6i), inoculum concentration and $\mathrm{Cd}(\mathrm{II})$ initial concentration (Fig. 6j), on $\mathrm{Cd}(\mathrm{II})$ biosorption from aqueous solution using bacterial isolates from sawdust. A high level of complementary interactive effects was exhibited among the investigated factors at different levels for the biosorption process. The plots were executed via plotting any two independent variables against each other while other variables were held constant. All actual factors were kept constant as Level 1 , such that $\mathrm{pH}$, temperature, time, inoculum concentration and $\mathrm{Cd}(\mathrm{II})$ initial concentration values were 2, $303 \mathrm{~K}$, $1 \mathrm{hr}, 5 \mathrm{v} / \mathrm{v}(\%)$ and $50 \mathrm{mg} / \mathrm{L}$, respectively. The percentage of Cd(II) removed from aqueous solution was greater than $76 \%$ in each of the plots. This affirms the high efficacy of bacterial isolates from sawdust as an effective biosorbent for $\mathrm{Cd}(\mathrm{II})$ removal from aqueous solution.

\section{Bacterial isolate characterization}

\section{Fourier transform infrared spectroscopy (FTIR)}

Figures $7 \mathrm{a}$ and $7 \mathrm{~b}$ present the FTIR spectra of bacterial isolates from waste sawdust, before and after $\mathrm{Cd}(\mathrm{II})$ biosorption from aqueous solution. Presence of sharp peaks is a strong indication that active functional groups are present on the surface of bacterial isolates (Haq et al., 2015). A shift in sharp peaks is a strong indication that biosorption of the contaminant has taken place (Popoola, 2019b). Major sharp peaks observed at 3 583.41; 2925.74 and $2396.11 \mathrm{~cm}^{-1}$ before Cd(II) removal (Fig. 7a) shifted to $3436.33 ; 2929.5$ and $2355.43 \mathrm{~cm}^{-1}$, respectively, after $\mathrm{Cd}$ (II) removal from aqueous solution (Fig. 7b). The major assignment at these respective wavelengths could be attributed to $-\mathrm{OH}$ stretching (Chojnacka et al., 2005), suggesting that this functional group is responsible for binding the metallic ions present in solution. Presence of the $-\mathrm{OH}$ group on the bacterial surface makes its surface negatively charged, which enhances the removal of positively charged Cd(II) from aqueous solution at a higher solution $\mathrm{pH}$. This is a strong indication of bacteria isolates ability to take up Cd(II) from aqueous solution.

\section{Scanning electron microscopy (SEM)}

The SEM image of bacterial isolates from sawdust before (Fig. 8a) and after Cd(II) removal (Fig. 8b) are shown in Fig. 8. A porous morphological nature was shown before Cd(II) removal, which enhances the biosorption of the contaminant from aqueous solution. After the removal, the multiple layers of walls on the bacterial inner surface were seen to be covered with the Cd(II) ion, suggesting the effectiveness of the bacterial isolates as a biosorbent for Cd(II) in aqueous solution (Abou-Taleb et al. 2017).

\section{Bacterial isolate characterization}

Table 8 presents the characterization of the bacterial isolates. The isolates were found to be motile when examined under the microscope. The isolates did not ferment glucose, sucrose, mannose and lactose and also exhibited gram-negative reaction attributes. They produce blue-green pigment and responded negatively to methyl red. However, the isolates responded positively to catalase, oxidase and citrate tests (Lennox et al., 2019; Hossain et al., 2013; Zhang et al., 2018).

Table 7. Comparison between Cd removal results in literature with the results of this study at optimum conditions

\begin{tabular}{|c|c|c|c|c|c|c|c|}
\hline \multirow[t]{2}{*}{ Adsorbent } & \multirow[t]{2}{*}{$\mathrm{pH}$} & Temp. & Time & $\begin{array}{c}\text { Inoculum } \\
\text { conc. }\end{array}$ & $\begin{array}{l}\text { Contaminant } \\
\text { intial conc. }\end{array}$ & Efficiency & \multirow[t]{2}{*}{ Reference } \\
\hline & & $(\mathrm{K})$ & (hr) & v/v (\%) & (mg/L) & (\%) & \\
\hline Pseudomonas putida & 6 & 303 & 1 & - & - & 71.00 & Pardo et al., 2003 \\
\hline Bacillus circulan & 7 & 293 & 2 & 0.5 & - & 63.58 & Yilmaz et al., 2005 \\
\hline Fireworks-exposed soil & 6 & 308 & 12 & 8 & 20 & 90.00 & Kumar et al., 2012 \\
\hline Dracaena draca & 7 & - & - & 0.5 & 10 & 79.60 & Mahmoud et al., 2016 \\
\hline Escherichia coli & 8 & 313 & 1 & 0.01 & - & 68.58 & Tafakori et al., 2017 \\
\hline Ulva fasciata & 5 & 298 & 1 & 4 & 200 & 99.96 & El-Naggar et al., 2018b \\
\hline Bacteria isolates & 4 & 303 & 4 & 15 & 50 & 99.53 & This study \\
\hline
\end{tabular}

Table 8. Motility, sugar fermentation and biochemical tests of bacterial isolates from sawdust

\begin{tabular}{|c|c|c|c|c|c|c|c|c|c|c|c|}
\hline Test & Motility & Methyl red & Catalase & Glucose & Sucrose & Mannose & Lactose & Pigment & Oxidase & Gram reaction & Citrate \\
\hline Result & Positive & Negative & Positive & Negative & Negative & Negative & Negative & Blue-green & Positive & Negative & Positive \\
\hline
\end{tabular}




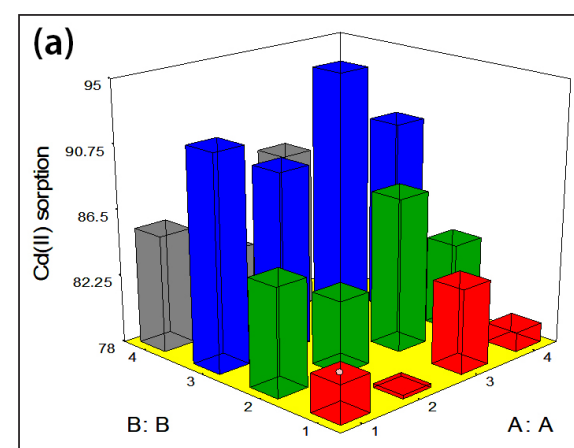

(c)

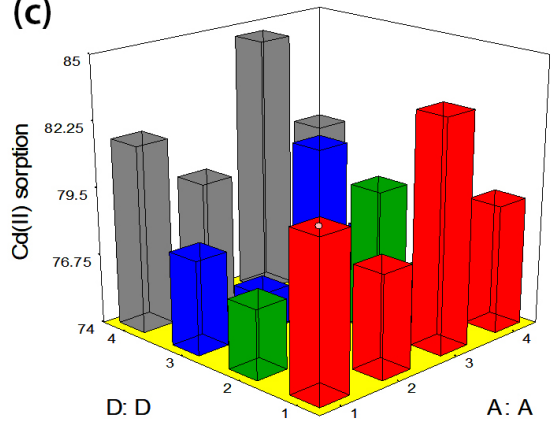

(e)

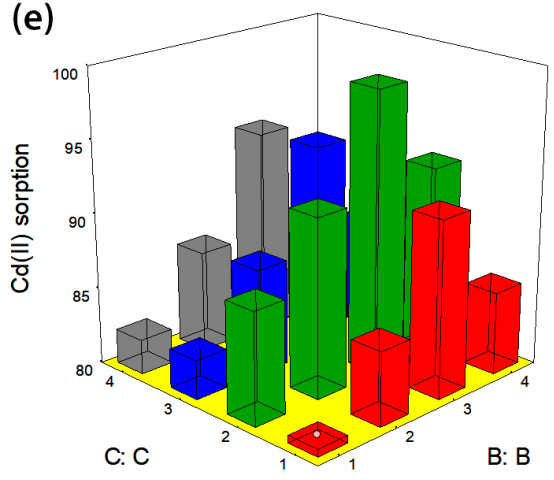

$(\mathrm{g})$
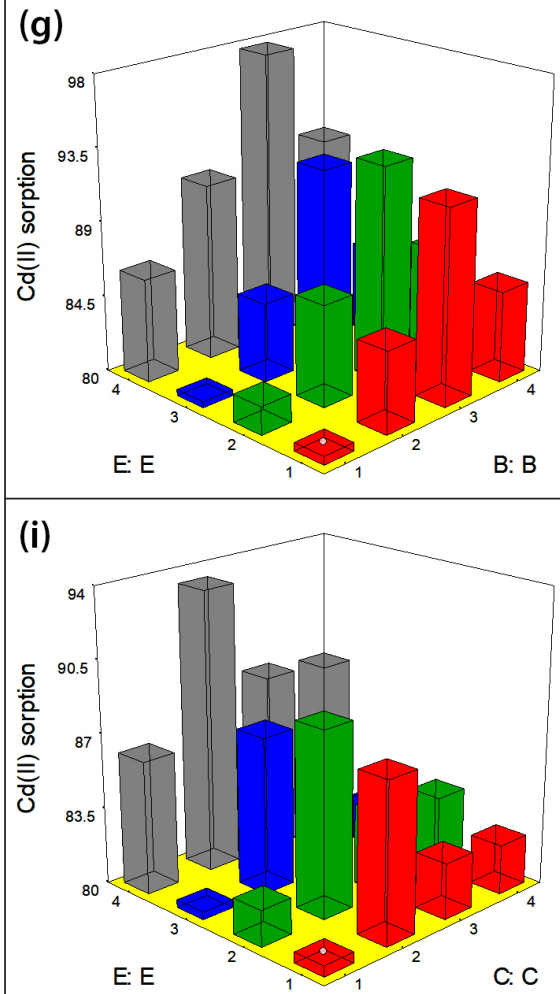

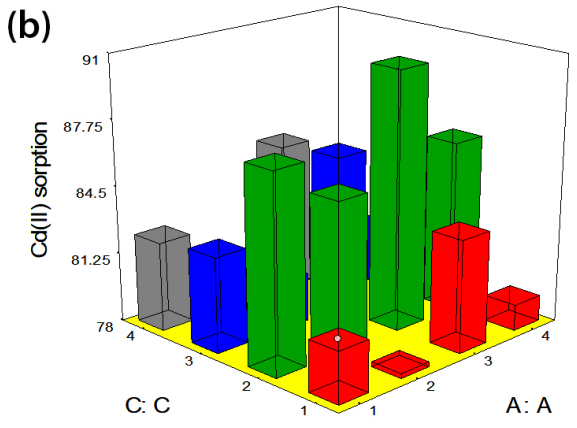

(d)

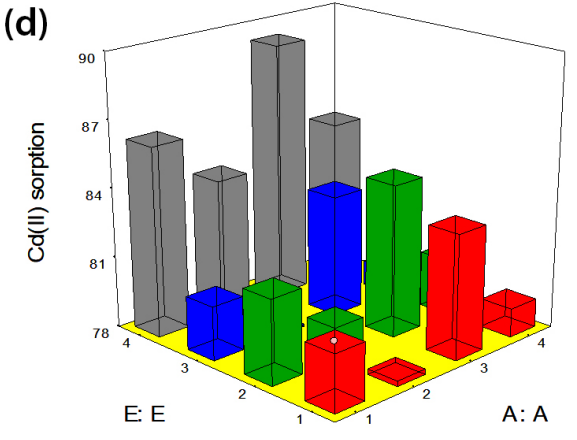

(f)

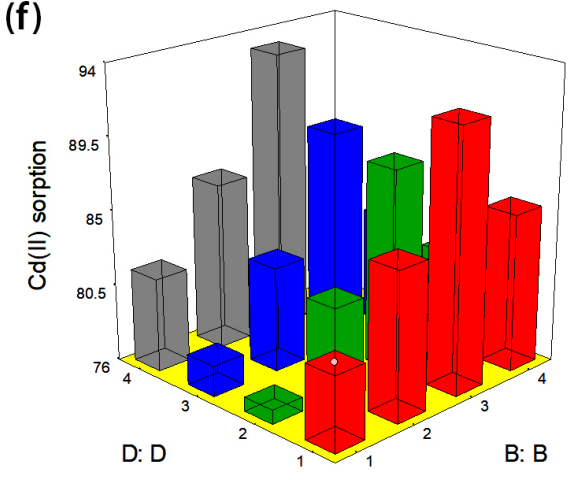

(h)

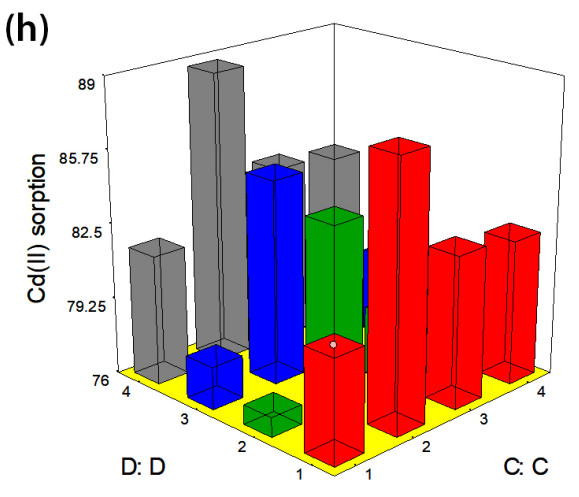

(j)

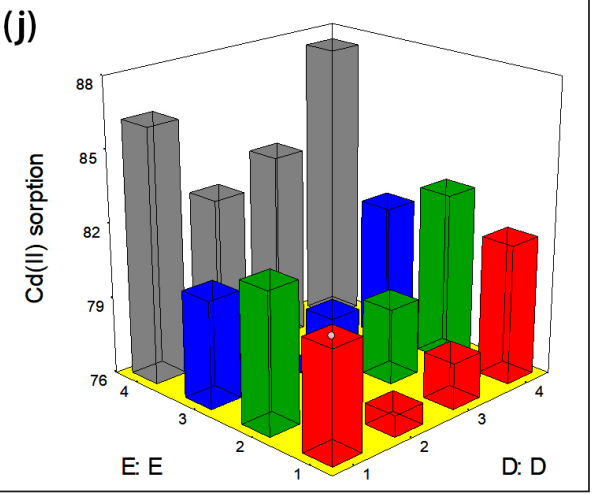

Figure 6. 3D surface plot of parameter interaction for (a) $\mathrm{pH}$ and temperature, (b) $\mathrm{pH}$ and time, (c) $\mathrm{pH}$ and inoculum concentration, (d) $\mathrm{pH}$ and $\mathrm{Cd}(\mathrm{II})$ initial concentration, (e) temperature and time, (f) temperature and inoculum concentration, (g) temperature and Cd(II) initial concentration, (h) time and inoculum concentration, (i) time and $\mathrm{Cd}$ (II) initial concentration, (j) inoculum concentration and $\mathrm{Cd}(\mathrm{II})$ initial concentration, on $\mathrm{Cd}$ (II) biosorption from aqueous solution using bacterial isolates from sawdust 


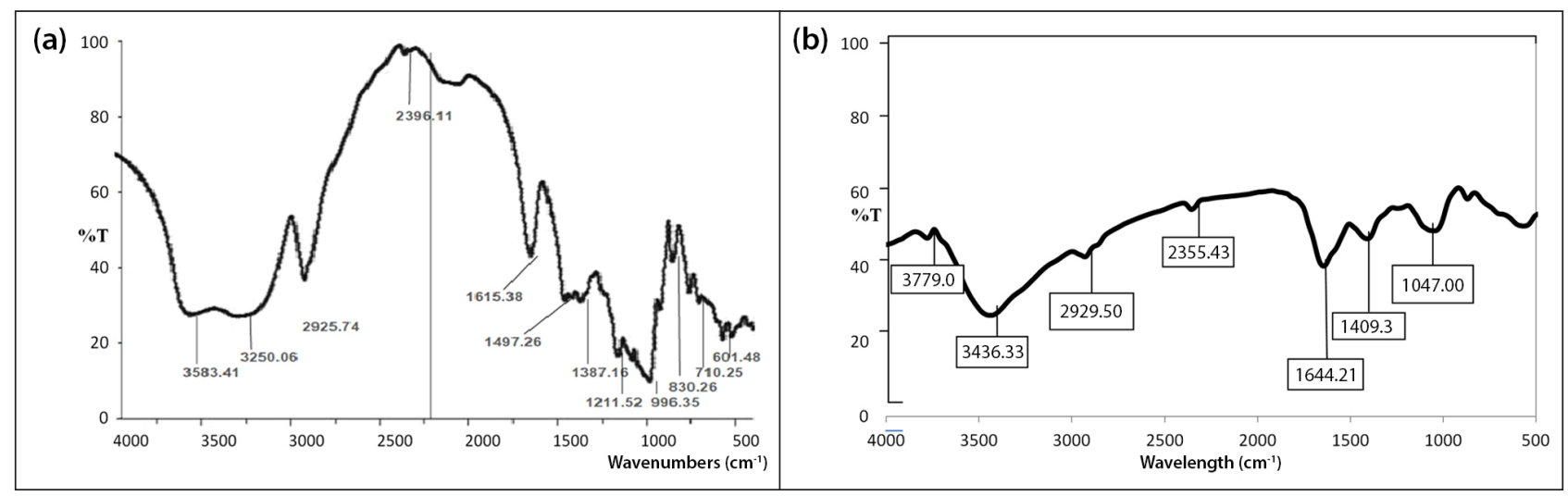

Figure 7. FTIR spectra of bacterial isolates from sawdust: (a) before, and (b) after Cd(II) removal

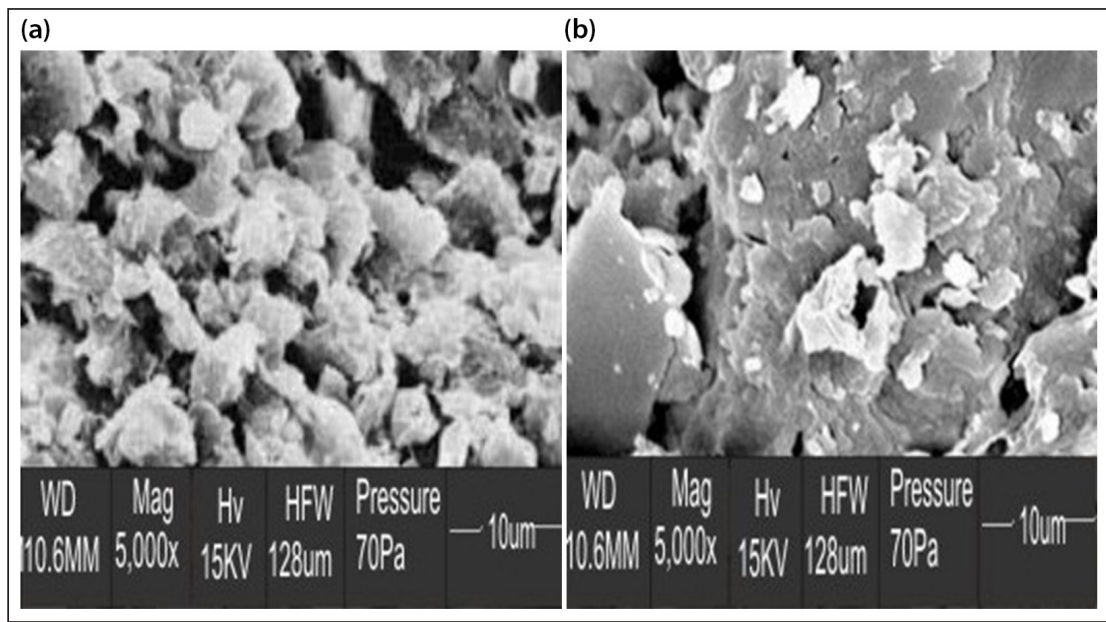

Figure 8. SEM image of bacterial isolates from sawdust: (a) before and (b) after Cd(II) biosorption

\section{Biosorption mechanism}

Different mechanisms of heavy metal biosorption from aqueous solution have been proposed and developed (Wu et al., 2010). In this study, the proposed mechanism of $\mathrm{Cd}(\mathrm{II})$ removal from solution using bacterial isolates from sawdust includes electrostatic interaction, surface complexation and ion exchange.

\section{Electrostatic interaction}

The FTIR analysis has revealed the presence of $-\mathrm{OH}$ groups on the bacterial isolates' (BI) surface, with three sharp peaks revealed indicating $-\mathrm{OH}$ stretching. The cadmium salt is a bivalent positively charged heavy metal ion with a strong affinity for negatively charged surface biosorbent. At high $\mathrm{pH}$, the surface of the bacteria is more negatively charged and, thus, loss of protons (deprotonation) occurs, with formation of water, as presented in Eq. 12 .

$$
\mathrm{BI}-\mathrm{OH}+\mathrm{OH}^{-} \rightarrow \mathrm{BI}-\mathrm{O}^{-}+\mathrm{H}_{2} \mathrm{O}
$$

Strong electrostatic forces then prevailed which enhanced the strong attraction between $\mathrm{Cd}(\mathrm{II})$ and bacterial isolates, as presented in Eq. 13.

$$
\mathrm{BI}-\mathrm{O}^{-}+\mathrm{Cd}^{2+} \rightarrow \mathrm{BI}-\mathrm{O}^{-\cdots \cdot \mathrm{Cd}}
$$

\section{Surface complexation}

At low $\mathrm{pH}$, the bacterial surface becomes more positively charged, and thus a gain of protons occurs (protonation), as presented in Eq. 14. As such, the protonated bacteria forms complexes at the cell surface.

$$
\mathrm{BI}-\mathrm{OH}+\mathrm{H}^{+} \rightarrow \mathrm{BI}-\mathrm{OH}_{2}^{+}
$$

The $\mathrm{Cd}(\mathrm{II})$ salt becomes more active as more bivalent ions are formed. More complexes are formed on the bacterial surface as shown in Eq. 15.

$$
\mathrm{BI}-\mathrm{OH}_{2}^{+}+\mathrm{Cd}^{2+} \rightarrow \mathrm{BI}-\mathrm{OH}_{2}^{+\ldots .} \mathrm{Cd}
$$

\section{lon exchange}

Under this mechanism, the counter ions $\left(\mathrm{X}^{+}\right)$present in polysaccharides (a main constituent of bacterial isolates' cell wall) are exchanged with bivalent cadmium ions resulting from covalent bonding between the two, as presented in Eq. 16 .

$$
\mathrm{X}^{+}+\mathrm{Cd}^{2+} \rightarrow \mathrm{Cd}^{+}+\mathrm{X}^{2+}
$$

\section{Other mechanisms}

Other proposed mechanisms, as suggested by previous studies, could be interaction with oxygen-containing functional groups (Fawzy et al., 2019); precipitation interaction involving inorganic minerals such as carbonates, phosphates, and silicates (Huang et al., 2018); and bioaccumulation and pore surface physical agglomeration (Iqbal et al., 2009).

\section{CONCLUSIONS}

The results obtained from this present study revealed bacterial isolates from sawdust to be an effective biosorbent for the biosorption of $\mathrm{Cd}(\mathrm{II})$ from aqueous solution. Taguchi experimental design with $\mathrm{L}_{16}$ 4-level factors orthogonal array was utilized to investigate the optimal process parameters that would give maximum percentage removal of $\mathrm{Cd}(\mathrm{II})$ from aqueous solution. The confirmatory experiment conducted at the predicted optimal conditions $(\mathrm{pH}=4$, temperature $=303 \mathrm{~K}$, time $=4 \mathrm{~h}$, inoculum concentration $=15 \mathrm{v} / \mathrm{v} \%$ and $\mathrm{Cd}(\mathrm{II})$ initial concentration $=50 \mathrm{mg} / \mathrm{L}$ ) revealed $99.53 \%$ removal for $\mathrm{Cd}(\mathrm{II})$. 
Analysis of variance revealed the order of factors' influence to be $\mathrm{Cd}(\mathrm{II})$ initial concentration $(33.87 \%)>$ time $(26.14 \%)>$ inoculum concentration $(20.05 \%)>$ temperature $(8.64 \%)>\mathrm{pH}(6.07 \%)$. Effect of parameter interaction revealed the percentage of Cd(II) removed from aqueous solution to be greater than $76 \%$ in each of the 3D surface plots. Fourier transform infrared analysis revealed the presence of $-\mathrm{OH}$ on the bacterial surface as the main active functional group enhancing Cd(II) biosorption. Scanning electron microscopy revealed the presence of small cavities on the bacterial surface, with a porous inner multilayer. Mechanisms of biosorption were proposed to be electrostatic interaction, surface complexation and ion exchange. With reference to these observations, bacterial isolates from sawdust could effectively be applied as biosorbent for $\mathrm{Cd}(\mathrm{II})$ removal from aqueous solution.

\section{REFERENCES}

ABDUlLA KJ, ALI SA, GATEA IH, HAMEED NA and MAIED SK (2019) Bio-degradation of crude oil using local bacterial isolates. IOP Conf. Series: Earth and Environmental Science. 388. 012081. https://doi.org/10.1088/1755-1315/388/1/012081

ABOU-TALEB KAA, EWEDA WE and MIRA HI (2017) Optimization of chromium and copper ions uptake by Aspergillus terreus strain using different techniques. Adv. Food Sci. Eng. 1 (1) 39-57. https:// doi.org/10.22606/afse.2017.11005

AKA RJN and BABALOLA OO (2016) Effect of bacterial inoculation of strains of Pseudomonas aeruginosa, Alcaligenes feacalis and Bacillus subtilis on germination, growth and heavy metal $(\mathrm{Cd}, \mathrm{Cr}$, and $\mathrm{Ni})$ uptake of Brassica juncea. Int. J. Phytoremed. 8 200-209. https://doi. org/10.1080/15226514.2015.1073671

AKSU Z and DÖNMEZ G (2000) The use of molasses in copper(II) containing wastewaters: effects on growth and copper(II) bioaccumulation properties of Kluyveromyces marxianus. Process Biochem.36451-458.https://doi.org/10.1016/S0032-9592(00)00234-X

AMINI M, YOUNESI $\mathrm{H}$, BAHRAMIFAR N, LORESTANI AAZ, GHORBANI F, DANESHI ALI and SHARIFZADEH M (2008) Application of response surface methodology for optimization of lead biosorption in an aqueous solution by Aspergillus niger. J. Hazardous Mater. 154 694-702. https://doi.org/10.1016/j.jhazmat. 2007.10.114

ATLAS RM and BARTHA R (1973) Stimulated biodegradation of oil slicks using oleophilic fertilizers. Environ. Sci. Technol. 7 538-541. https://doi.org/10.1021/es60078a005

BARRADO M, VEGA R, PARDON P and GRANDE JLD (1996) Optimization of a purification method for metal-containing wastewater by use of a Taguchi experimental design. Water Res. 30 2309-2314. https://doi.org/10.1016/0043-1354(96)00119-4

BOUAZIZI H, JOUILI H, GEITMANN A and FERJANI EEI (2010) Copper toxicity in expanding leaves of Phaseolus vulgaris L.: antioxidant enzyme response and nutrient element uptake. Ecotox. Environ. Saf. 73 1304-1308. https://doi.org/10.1016/j.eco env.2010.05.014

CHEESBROUGH M (1985) Medical laboratory manual for tropical countries. Microbiology. 2 248-264

CHELLAIAH ER (2018) Cadmium (heavy metals) bioremediation by Pseudomonas aeruginosa: a minireview. Appl. Water Sci. 8154. https://doi.org/10.1007/s13201-018-0796-5

CHOJNACKA K, CHOJNACKI A and GORECKA H (2005) Biosorption of $\mathrm{Cr}(\mathrm{III}), \mathrm{Cd}(\mathrm{II})$ and $\mathrm{Cu}(\mathrm{II})$ ions by blue-green algae Spirulina sp. Chemosphere. 59 75-84. https://doi.org/10.1016/j.che mosphere.2004.10.005

DANESHVAR N, KHATAEE AR, RASOULIFARD $\mathrm{MH}$ and POURHASSAN M (2007) Biodegradation of dye solution containing Malachite Green, optimization of effective parameters using Taguchi method. J. Hazardous Mater. 143 214-219. https://doi.org/ 10.1016/j.jhazmat.2006.09.016

DING Y, JING D, GONG H, ZHOU L and YANG X (2012) Biosorption of aquatic cadmium(II) by unmodified rice straw. Bioresour. Technol. 114 20-25. https://doi.org/10.1016/j.biortech.2012.01.110

DURSUN AY, USLU G, CUCI Y and AKSU Z (2003) Bioaccumulation of copper (II), lead (II) and chromium (VI) by growing Aspergillus niger. Process Biochem. 38 1647-1651. https://doi.org/10.1016/S00329592(02)00075-4
EL-NAGGAR NE, HAMOUDA RA, MOUSA IE, ABDEL-HAMID MS and RABEI NH (2018a) Biosorption optimization, characterization, immobilization and application of Gelidium amansii biomass for complete $\mathrm{Pb}^{2+}$ removal from aqueous solutions. Sci. Rep. 813456. https://doi.org/10.1038/s41598-018-31660-7

EL-NAGGAR NE, HAMOUDA RA, MOUSA IE, ABDEL-HAMID MS and RABEI NH (2018b) Statistical optimization for cadmium removal using Ulva fasciata biomass: Characterization, immobilization and application for almost-complete cadmium removal from aqueous solutions. Sci. Rep. 8 12456. https://doi.org/10.1038/s41598018-30855-2

ENGIN AB, OZDEMIR O, TURAN M and TURAN AZ (2008) Color removal from textile dye bath effluents in a zeolite fixed bed reactor: determination of optimum process conditions using Taguchi method. J. Hazardous Mater. 159 348-353. https://doi.org/10.1016/j. jhazmat.2008.02.065

FAWZY M, NASR M, ABDEL-RAHMAN AM, HOSNY G and ODHAFA BR (2019) Techno-economic and environmental approaches of $\mathrm{Cd}^{2+}$ adsorption by olive leaves (Olea europaea L.) waste. Int. J. Phytoremed. 21 (12) 1205-1214. https://doi.org/10.1080/152265 14.2019.1612848

GHANI JA, JAMALUDIN H, RAHMAN MNA and DEROS BM (2013) Philosophy of Taguchi approach and method in design of experiment. Asian J. Sci. Res. 6 (1) 27-37. https://doi.org/10.3923/ ajsr.2013.27.37

GUO J, ZHENG XD, CHEN QB, ZHANG L and XU XP (2012) Biosorption of $\mathrm{Cd}(\mathrm{II})$ from aqueous solution by Pseudomonas plecoglossicida. Curr. Microbiol. 65 350-355. https://doi.org/10.1007/ s00284-012-0164-X

HAMZA SM, AHMED HF and MOHAMMAD EAM (2010) Optimization of cadmium, zinc and copper biosorption in an aqueous solution by Saccharomyces cerevisiae. J. Am. Sci. 6 597-604.

HAQ F, BUTT M, ALI H and CHAUDHARY HJ (2015) Biosorption of cadmium and chromium from water by endophytic Kocuria rhizophila: Equilibrium and kinetic studies. Desalin. Water Treat. 20 (15) $1-13$.

HARITASH AK and KAUSHIK CP (2009) Biodegradation aspects of polycyclic aromatic hydrocarbons (PAHs): a review. J Hazardous Mater. 169 1-15. https://doi.org/10.1016/j.jhazmat.2009.03.137

HE HJ, XIANG ZH and CHEN XJ (2018) Biosorption of Cd (II) from synthetic wastewater using dry biofilms from biotrickling filters. Int. J. Environ. Sci. Technol. 15 (7) 1491-1500. https://doi.org/10.1007/ s13762-017-1507-8

HOSSAIN MG, SAHA S, RAHMAN MM, SINGHA JK and MAMUN AA (2013) Isolation, identification and antibiogram study of Pseudomonas aeruginosa from cattle in Bangladesh. J. Vet. Adv. 3 (7) 180-185. https://doi.org/10.5455/jva.20130717123841

HRISTOV J (2014) The role and use of water in agriculture in the Western Balkans: The case of Macedonia. PhD thesis, Swedish University of Agricultural Sciences.

HU JL, HE XW, WANG CR, LI JW and ZHANG CH (2012) Cadmium adsorption characteristic of alkali modified sewage sludge. Bioresour. Technol. 121 25-30. https://doi.org/10.1016/j.biortech.2012.06.100

HUANG J, LIU Z, LI S, XU B, GONG Y, YANG Y and SUN H (2016) Isolation and engineering of plant growth promoting rhizobacteria Pseudomonas aeruginosa for enhanced cadmium bioremediation. J Gen. Appl. Microbiol. 62 258-265. https://doi.org/10.2323/jgam. 2016.04.007

HUANG Q, CHEN Y, YU H, YAN L, ZHANG J, DU BWB and XING L (2018) Magnetic graphene oxide/MgAl-layered double hydroxide nanocomposite: One-pot solvothermal synthesis, adsorption performance and mechanisms for $\mathrm{Pb}^{2+}, \mathrm{Cd}^{2+}$ and $\mathrm{Cu}^{2+}$. Chem. Eng. J. 341 1-9. https://doi.org/10.1016/j.cej.2018.01.156

IQBAL M, SAEED A and ZAFAR SI (2009) FTIR spectrophotometry, kinetics and adsorption isotherms modeling, ion exchange, and EDX analysis for understanding the mechanism of $\mathrm{Cd}^{2+}$ and $\mathrm{Pb}^{2+}$ removal by mango peel waste. J. Hazardous Mater. 164 (1) 161-171. https://doi.org/10.1016/j.jhazmat.2008.07.141

JACOB JM, KARTHIK C and SARATALE RG (2018) Biological approaches to tackle heavy metal pollution: A survey of literature. J. Environ. Manage. 217 56-70. https://doi.org/10.1016/j.jenvman. 2018.03.077 
JAVANBAKHT V, ALAVI SA and ZILOUEI H (2014) Mechanisms of heavy metal removal using microorganisms as biosorbent. Water Sci. Technol. 69 (9) 1775-1787. https://doi.org/10.2166/wst.2013.718

KASSAB DM and ROANE TM (2006) Differential responses of a mine tailings Pseudomonas isolate to cadmium and lead exposures. Biodegradation. 17 379-387. https://doi.org/10.1007/s10532-005-90 $10-1$

KUMAR A, BISHT BS and JOSHI VD (2010) Biosorption of heavy metals by four acclimated microbial species, Bacillus sp., Pseudomonas sp., Staphylococcus sp. and Aspergillus niger. J. Biol. Environ. Sci. 4 97-108.

LENNOX JA, ASITOK A, JOHN GE and ETIM BT (2019) Characterization of products from sawdust biodegradation using selected microbial culture isolated from it. Afr. J. Biotechnol. 18 (29) 857-864.

MACFADDEN JF (2000) Biochemical Tests for Identification of Medical Bacteria ( $3^{\text {rd }}$ edn.). The Williams \& Wilkins Co., Baltimore/. 689-691.

MAHMOUD AED, FAWZY M and RADWA AA (2016) Optimization of cadmium $\left(\mathrm{Cd}^{2+}\right)$ removal from aqueous solutions by novel biosorbent. Int. J. Phytoremed. 18 (6) 619-625. https://doi.org/10.108 0/15226514.2015.1086305

MARQUES APGC, RANGEL AOSS and CASTRO PML (2009) Remediation of heavy metal contaminated soils: phytoremediation as a potentially promising clean-up technology. Crit. Rev. Environ. Sci. Technol. 39 (8) 622-654. https://doi.org/10.1080/10643380701798272

MKADMI Y, BENABBI O, FEKHAOUI M, BENAKKAM R, BJIJOU W, ELAZZOUZI M, KADOURRI M and CHETOUANI A (2018) Study of the impact of heavy metals and physico-chemical parameters on the quality of the wells and waters of the Holcim area (Oriental region of Morocco). J. Mater. Environ. Sci. 9 (2) 672-679.

MOUSAV S, YAGHMAEI A, JM VOSSOUGHI and GHOBADI Z (2007) Optimization of ferrous biooxidation rate in a packed bed bioreactor using Taguchi approach. Chem. Eng. Process. 46 935-940. https:// doi.org/10.1016/j.cep.2007.06.010

NAGENDRAPPA G, BHASKAR CV and KUMAR K (2010) Assessment of heavy metals in water samples of certain locations situated around Tumkur, Karnataka India. J. Chem. 7 (2) 349-352. https:// doi.org/10.1155/2010/415150

PARDO R, HERGUEDAS M, BARRADO E and VEGA M (2003) Biosorption of cadmium, copper, lead and zinc by inactive biomass of Pseudomonas putida. Anal. Bioanal. Chem. 376 (1) 26-32. https:// doi.org/10.1007/s00216-003-1843-Z

PATRÓN-PRADO M, ACOSTA-VARGAS B, SERVIERE-ZARAGOZA E and MÉNDEZ-RODRÍGUEZ L (2010) Copper and cadmium biosorption by dried seaweed Sargassum sinicola in saline wastewater. Water, Air Soil Pollut. 210 197-202. https://doi.org/ 10.1007/s11270-009-0241-3

PÉREZ-RAMA M, TORRES E, SUÁREZ C, HERRERO C and ABALDE J (2010) Sorption isotherm studies of Cd(II) ions using living cells of the marine microalga Tetraselmis suecica (Kylin) Butch. J. Environ. Manage. 91 2045-2050. https://doi.org/10.1016/j. jenvman.2010.05.014

POPOOLA LT (2019a) Tetracycline and sulfamethoxazole adsorption onto nanomagnetic walnut shell-rice husk: isotherm, kinetic, mechanistic and thermodynamic studies. Int. J. Environ. Anal. Chem. 100 (9) 1021-1043. https://doi.org/10.1080/03067319.2019.16 46739

POPOOLA LT (2019b) Nano-magnetic walnut shell-rice husk for Cd(II) sorption: design and optimization using artificial intelligence and design expert. Heliyon. 5 1153. https://doi.org/10.1016/j.heliyon.2019. e02381

POPOOLA LT, ADERIBIGBE TA, YUSUFF AS and MUNIR MM (2018) Brilliant green dye adsorption onto composite snail shell-rice husk: Adsorption isotherm, kinetic, mechanistic and thermodynamics analysis. Environ. Qual. Manage. 1 16. https://doi.org/10.1002/tqem. 21597

PUNDIR R, CHARY GHVC and DASTIDAR MG (2018) Application of Taguchi method for optimizing the process parameters for the removal of copper and nickel by growing Aspergillus sp. Water Resour. Ind. 20 83-92. https://doi.org/10.1016/j.wri.2016.05.001
RAJESHKUMAR R, SAHU S and AGHARWAL JR (2012) Biosorption of cadmium (II) ions by the cadmium tolerant bacteria isolated from the chemical exposed soil of fireworks industry. J. Pure Appl. Microbiol. 6 (2) 781-787.

RAO MM, RAMESH A, RAO GPC and SESHAIAH K (2006) Removal of copper and cadmium from the aqueous solutions by activated carbon derived from Ceiba pentandra hulls. J. Hazardous Mater. 129 (1) 123-129. https://doi.org/10.1016/j.jhazmat.2005.08.018

REHMAN R, FAROOQ S and MAHMUD T (2019) Use of agro-waste Musa acuminata and Solanum tuberosum peels for economical sorptive removal of emerald green dye in ecofriendly way. J. Clean. Prod. 206 819-826. https://doi.org/10.1016/j.jclepro.2018.09.226

SALMAN M, REHMAN R, FAROOQ U, TAHIR A and MITU L (2020) Biosorptive removal of cadmium(ii) and copper(ii) using microwaveassisted thiourea-modified sorghum bicolor agrowaste. J. Chem. 2020 Article ID 8269643. 11 pp. https://doi.org/10.1155/2020/8269643

SANKARAMMAL M, THATHEYUS A and RAMYA D (2014) Bioremoval of cadmium using Pseudomonas fluorescens. Open J. Water Pollut. Treat. 1 92-100. https://doi.org/10.15764/WPT.2014. 02010

SHARMA PK, BALKWILL DL, FRENKEL A and VAIRAVAMURTHY MA (2000) A new Klebsiella planticola strain (Cd-1) grows anaerobically at high cadmium concentrations and precipitates cadmium sulfide. Appl. Environ. Microbiol. 66 3083-3087. https:// doi.org/10.1128/AEM.66.7.3083-3087.2000

SINGH B, ALLOWAY BJ and BOCHEREAU FJM (2000) Cadmium sorption behaviour of natural and synthetic zeolites. Commun. Soil Sci. Plant Anal. 3117 2775-2786. https://doi.org/ 10.1080/00103620009370626

SRIDEVI V, LAKSHMI MVVC, SWAMY AVN and RAO MN (2011) Implementation of response surface methodology for phenol degradation using Pseudomonas putida (NCIM 2102). J Bioremed. Biodegrad. 2 (2) 1-7. https://doi.org/10.4172/2155-6199.1000121

TAFAKORI V, ZADMARD R, TABANDEH F, AMOOZEGAR MA and AHMADIAN G (2017) Equilibrium isotherm, kinetic modeling, optimization, and characterization studies of cadmium adsorption by surface-engineered Escherichia coli. Iran. Biomed. J. 21 (6) $380-391$.

WU G, KANG H, ZHANG X, SHAO H, CHU L and RUAN C (2010) A critical review on the bio-removal of hazardous heavy metals from contaminated soils: Issues, progress, eco-environmental concerns and opportunities. J. Hazardous Mater. 174 (1-3) 1-8. https://doi. org/10.1016/j.jhazmat.2009.09.113

WU M, LIU H and YANG C (2019) Effects of pretreatment methods of wheat straw on adsorption of Cd (II) from waterlogged paddy soil. Int. J. Environ. Res. Public Health. 16 (2) 205-211. https://doi. org/10.1016/j.jhazmat.2009.09.113

YALÇIN S, SEZER S and APAK R (2012) Characterization and lead (II), cadmium(II), nickel(II) biosorption of dried marine brown macro algae Cystoseira barbata. Environ. Sci. Pollut. Res. 19 3118-3125. https://doi.org/10.1007/s11356-012-0807-2

YAN G and VIRARAGHAVAN T (2003) Heavy-metal removal from aqueous solution by fungus Mucor rouxii. Water Res. 37 4486-4496. https://doi.org/10.1016/S0043-1354(03)00409-3

YILMAZ EI and ENSARI NY (2005) Cadmium biosorption by Bacillus circulans strain EB1. World J. Microbiol. Biotechnol. 21 (5) 777-779. https://doi.org/10.1007/s11274-004-7258-y

ZHANG H, KRAFFT T, GAO D, ZHENG G and CAI L (2018) Lignocellulose biodegradation in the biodrying process of sewage sludge and sawdust. Drying Technol. 36 (3) 316-324. https://doi.org/ 10.1080/07373937.2017.1326502

ZOUBOULIS A, LOUKIDOU M and MATIS K (2004) Biosorption of toxic metals from aqueous solutions by bacteria strains isolated from metal-polluted soils. Process Biochem. 39 909-916. https://doi. org/10.1016/S0032-9592(03)00200-0 